\title{
Key factors in learners' satisfaction with the e-learning system at the University of Dar es Salaam, Tanzania
}

\author{
Joel S. Mtebe \\ University of Dar es Salaam, Tanzania \\ Christina Raphael \\ Dar es Salaam University College of Education, Tanzania
}

\begin{abstract}
This study aimed to identify key factors that have an influence on learners' satisfaction with the e-learning system at the University of Dar es Salaam, Tanzania, using a modified, updated DeLone and McLean (D\&M) (2003) model. The research model was tested against regression analysis using a sample of 153 enrolled students. The study found that system quality, instructor quality, and service quality had a significant positive effect on learners' satisfaction, with service quality being the strongest predictor. However, course quality was found to have no significant effect on learners' satisfaction with the e-learning system. The findings from this study will help institutions that are planning or implementing e-learning systems to enhance learners' satisfaction and, consequently, increase systems success. The implications of these findings are discussed.
\end{abstract}

\section{Introduction}

The adoption and use of various e-learning systems such as Moodle, Sakai, and Blackboard to enhance teaching and learning are gaining popularity in higher education in sub-Saharan Africa (Ssekakubo, Suleman, \& Marsden, 2011; Unwin et al., 2010; Venter, van Rensburg, \& Davis, 2012). Countries such as Kenya, Mozambique (Unwin et al., 2010), Uganda (Mayoka \& Kyeyune, 2012), Sudan (Elmahadi \& Osman, 2013), Zimbabwe (Chitanana, Makaza, \& Madzima, 2008), South Africa (Bagarukayo \& Kalema, 2015; Venter et al., 2012), and Tanzania (Lwoga, 2012; Mtebe, Dachi, \& Raphael, 2011) have adopted e-learning systems of various kinds. For instance, Moodle has 81,397 active sites registered from 234 countries (Moodle, 2017). Out of those sites, 53 sites registered from Tanzania, 178 sites registered from Kenya, and 49 sites registered from Uganda.

E-learning systems are web-based software for distributing, tracking, and managing courses over the Internet (Islam \& Azad, 2015). They contain features such as chat rooms, whiteboards, discussion forums, polls, quizzes and surveys which allow instructors and students to share course content and communicate online synchronously and asynchronously (Naveh, Tubin, \& Pliskin, 2010). Institutions tend to use these systems to enhance the quality of face-to-face delivery by enabling learners to independently access course content (Lee \& Hsiao, 2014; Vovides, Sanchez-Alonso, Mitropoulou, \& Nickmans, 2007). Other institutions use them to offer blended distance delivery to reach more learners across various geographical boundaries (Andersson \& Grönlund, 2009; Islam \& Azad, 2015).

The continued adoption of these systems has increased revenue in many countries. The marketplace worldwide was over \$3 billion in 2016 and was expected to grow at a rate of 24\% from 2016 to 2020 (Docebo, 2016). A report by Adkins (2016) projected the increase in revenue to $\$ 636.3$ million by 2021 . In addition to increased revenue, these systems have created high expectations for pedagogical changes that will improve the quality of education (Naveh, Tubin, \& Pliskin, 2012) as well as enable institutions to widen access to higher education in sub-Saharan Africa. The potential for the increased use of these systems in Africa is also due to the emergence of fibre cable marines in Africa, which have increased Internet speed up to 155mbps (Mtebe, 2015). These submarine cables include the East African Submarine Cable System, SEACOM, and the East African Marine System (Wainaina, Sanou, \& Boateng, 2014). Africa is also the fastest growing telecommunication sector in the world (Vosloo, 2012; World Bank, 2012). In 2012, for instance, there were almost 650 million mobile subscriptions in Africa, more than in the United States or the European Union (World Bank, 2012). 
Despite these technological developments, studies in higher education in sub-Saharan Africa have found that the full potential of these systems is not realised (Bagarukayo \& Kalema, 2015; Unwin et al., 2010; Wu, Tsai, Chen, \& Wu, 2006). Many installed systems consist of inactive users and/or users who use relatively small features. Studies have also found low usage or non-use of these systems in various institutions in countries such as Uganda (Mayoka \& Kyeyune, 2012), Kenya, Zambia (Ssekakubo et al., 2011), Tanzania (Mtebe \& Raisamo, 2014), and Zimbabwe (Chitanana et al., 2008; Dube \& Scott, 2014). Studies have pointed out inadequate technical support, poor Internet connectivity, lack of e-learning policies, high costs of technology, and poor technological infrastructure as inhibitors to the use of these systems (Mlitwa \& Van Belle, 2011; Ssekakubo et al., 2011; Unwin et al., 2010; Venter et al., 2012).

Although technological infrastructure is improving, little is known about why some users tend to stop using these systems after their initial experience (Sun, Tsai, Finger, Chen, \& Yeh, 2008). Therefore, there is a need to seek a deeper understanding of how users perceive these systems (Venter et al., 2012). The majority of studies to date have focused on technological and infrastructural challenges with fewer efforts on assessing learners' satisfaction with these systems. Understanding whether learners are satisfied with the system is critical in determining whether it is effective or not (Au, Ngai, \& Cheng, 2002). Learners with high levels of satisfaction are likely to use the system more often than dissatisfied ones (Baroudi, Olson, \& Ives, 1986) and eventually take more courses (Booker \& Rebman, 2005; Tarigan, 2011; Wang, 2003). Thus, this study aimed to determine key factors in learners' satisfaction with the e-learning system at the University of Dar es Salaam (UDSM) in Tanzania through adopting and modifying the updated DeLone and McLean (D\&M) (2003) model. Data was collected from 153 students enrolled in various courses offered via Moodle.

\section{E-learning systems adoption at UDSM}

The use of e-learning systems to enhance teaching and learning at UDSM can be traced back to the 1990s, when the university acquired the Blackboard system under the Technology Enhanced Independent Learning (TEIL) project. Through this initiative, intensive training was conducted on how to use the system. A total of 402 courses were created and uploaded by the end of 2007 (Mtebe et al., 2011). Similarly, approximately 16,000 users were registered in the system. However, one of the major weaknesses of early initiatives was that they focused on motivating staff to use the system rather than on the pedagogy (Mtebe et al., 2011). As a result, many of the uploaded courses had course titles without content or with minimal content (Twaakyondo \& Munaku, 2012). Also, during that time, the university was paying approximately US\$18,000 annually as license fees for using Blackboard, which seemed to be very costly to the university, particularly because the fee was covered through the project (Mtebe et al., 2011). When the project ended, the university had to look for an open source system as an alternative.

The university started by adopting Knowledge Environment for Web-based Learning (KEWL) as an alternative. KEWL was developed at the University of the Western Cape to facilitate research of technology-enhanced education in the African context. Nevertheless, during the evaluation, the system had many features under development. The decision to choose a more robust and stable system was made and Moodle was preferred (Twaakyondo \& Munaku, 2012). An audit was carried out to identify courses relevant to various programs and curricula, and with a reasonable amount of course content, sizable user enrolment, and high numbers of postings on discussion boards to be migrated to Moodle. The audit revealed that 146 courses met the criteria to be migrated to Moodle (Mtebe et al., 2011).

Since the migration to Moodle, the university has continued to equip instructors and students with the necessary skills as well as facilities so that they can use the system more effectively. To date, there are more than 15,000 active users who are using the system, with more than 400 courses. Migration from Blackboard to Moodle was accompanied by the introduction of three postgraduate blended distance programs: Postgraduate Diploma in Education, Postgraduate Diploma in Engineering Management, and Master in Engineering Management (Mtebe \& Raphael, 2013). These programs were offered via regional centres in Mbeya, Mwanza, Dar es Salaam, and Arusha. The UDSM blended distance programs combined face-to-face delivery with students accessing 
learning resources via Moodle. Instructors use Moodle to facilitate course delivery, using system tools such as discussion forums, assignments, and chat forums. Thus far, studies have been conducted on various aspects of e-learning at the university. Nevertheless, little has been done to understand students' satisfaction with the elearning system. Since 2007, a total of 111 Postgraduate Diploma in Engineering Management students, 138 Master in Engineering Management students, and 61 Postgraduate Diploma in Education students have been admitted. By the end of 2016, more than 200 students had graduated and several others were at different levels of their research work.

\section{Literature review}

User satisfaction has been a popular measure of information system effectiveness and has served mostly as a surrogate measure for the other dimensions of system success (Au et al., 2002; Cai, Jun, \& Pham, 2007; DeLone \& McLean, 1992, 2016; Xiao \& Dasgupta, 2002). According to Doll and Torkzadeh (1988), user satisfaction is an affective attitude towards a specific computer application by someone who interacts with the application directly. It involves gathering perceptions and feelings about the system from direct users of the system (Au et al., 2002; Xiao \& Dasgupta, 2002). Thus, users’ perceived satisfaction significantly impacts the degree to which the system is considered reliable; thus, it is very critical in deciding whether it will continue to be used or not (Shee \& Wang, 2008). In fact, when the system is perceived as poor by users, regardless of any evaluation results, the system is indeed poor (Ives, Olson, \& Baroudi, 1983).

Many studies have been conducted to develop tools that can be used to measure user satisfaction of information systems in various contexts. The earliest tool was developed by Bailey and Pearson (1983) with 39 items, with information quality, systems performance, personal relationship with staff, and top management involvement as the main factors for measuring users' satisfaction. However, since the scales were developed and validated for mainframe computer systems, their applicability to personal computers remained in doubt (Au et al., 2002). As a result, Ives et al. (1983) improved and validated the tool using information provided by the data processing group of the organisation. Nevertheless, the major weakness of the tool was that it was based on the data processing computing environment (Xiao \& Dasgupta, 2002) and thus could not be used in the web-based environment.

Doll and Torkzadeh (1988) developed a tool to measure user satisfaction by contrasting the traditional data processing environment and the end-user computing environment. The tool consisted of five components: content, accuracy, format, ease of use, and timeliness. The model has been widely used and validated by several studies. The majority of these components were later included in the information quality factor described in the updated D\&M research model.

Many studies have shown that the tools discussed above do not have the ability to measure user satisfaction in web-based systems and e-learning environments in particular (Xiao \& Dasgupta, 2002). As a result, some researchers have tried to improve these tools so that they can be relevant in measuring user satisfaction in an elearning environment. Naveh et al. (2012) developed a tool featuring content completeness, content currency, ease of navigation, ease of access, and course staff responsiveness as factors to measure learners' satisfaction. The tool was tested using a sample of 8,425 respondents; all factors had an effect on learners' satisfaction with the e-learning system in a university in Israel.

Horvat, Dobrota, Krsmanovic, and Cudanov (2013) developed a tool with seven factors - average waiting for time for a response, feedback quality, material thoroughness, material clarity, website user-friendliness, cooperation diversity, and material quantity - that could be used to assess learners' satisfaction with Moodle at the University of Belgrade in Serbia. Similarly, Eom (2014) developed a tool with information quality, readiness, and self-efficacy, and self-regulated learning management as factors to measure learner satisfaction with the WarpPLS system.

Using a sample of 503 undergraduate students at the University of Botswana, Tella (2012) found that net benefits, self-regulated learning, content quality, teaching/learning quality, system quality, and service quality 
had an influence on users' satisfaction with Blackboard. Moreover, the factors jointly predicted 54\% of the variation in the students' satisfaction.

Another widely adopted tool in evaluating user satisfaction with e-learning systems was proposed by Wang (2003). The tool consists of four factors: learner interface, learning community, system content, and personalisation. It has been used to measure learners' satisfaction with e-learning systems in various contexts (e.g., Danesh, Hashemnia, Sirousbakht, \& Kia, 2013; Hisham, Campton, \& FitzGerald, 2004; Katsidis \& Anastasiades, 2008; Shee \& Wang, 2008; Tarigan, 2012). However, this tool failed to include other factors, such as system support and perceived usefulness, which have been described by many studies (e.g., DeLone \& McLean, 2003; Lwoga, 2014) to have an effect on learners’ satisfaction with e-learning systems.

The variability of tools described in the studies discussed above clearly indicates that there is no single tool that has been validated so far to measure learners' satisfaction with e-learning systems. This study adopted and modified updated the D\&M model (DeLone \& McLean, 2003) to measure learners' satisfaction with the elearning system at UDSM. The description of the research model, factors, and hypothesis of the modified proposed research model follow.

\section{The research model}

The increased expenditure on information systems in higher education institutions has made its evaluation one of the most studied topics in information systems literature. Several models and tools have been developed to assess the effectiveness of information systems implemented in various settings. The most dominant models which have been cited in more than 10,000 articles and used to evaluate dozens of information systems worldwide are the original and the updated D\&M models (Petter, DeLone, \& McLean, 2008). The original D\&M model (DeLone \& McLean, 1992) consists of six factors: system quality, information quality, system use, user satisfaction, individual impact, and organisational impact.

In 2003, the D\&M model was reviewed by several researchers to enable it to cope with the changing information technology (IT) industry (DeLone \& McLean, 2003). The model was extended by splitting the use factor into intention to use and use to measure systems success in areas where the use of the system is voluntary and mandatory. Also, service quality was added as a new factor to measure the quality of services offered by the IT units established in many organisations to provide information system services to users. The updated D\&M model has six factors: information quality, system quality, service quality, intention to use/use, user satisfaction, and net benefits. Figure 1 shows the updated D\&M model.

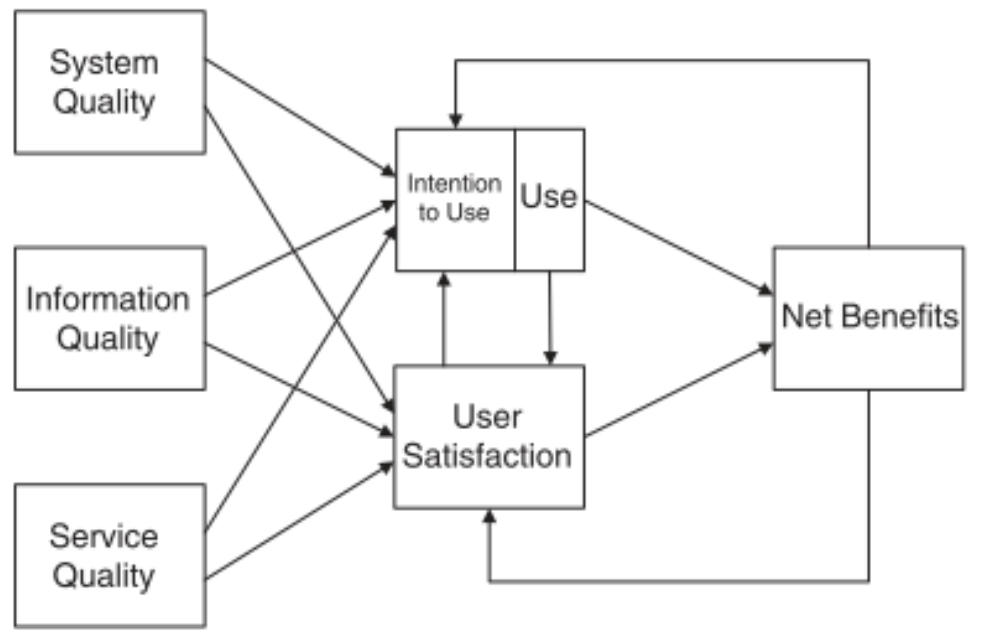

Figure 1. The updated D\&M model (DeLone \& McLean, 2003, p. 24) 
DeLone and McLean (2003) argued that the updated D\&M model was not a generic model for measuring information system success. They suggested that researchers add or reduce the number of factors so that the model is relevant in their context. Accordingly, recent developments in e-learning systems have heightened the need to extend the D\&M model to measure the success of these systems in various educational settings. Studies to extend the D\&M model into the e-learning context include Hassanzadeh, Kanaani, and Elahi (2012), Holsapple and Lee-Post (2006), and Ozkan and Koseler (2009). Despite several attempts to extend the updated D\&M model to develop models to assess the success of e-learning systems, most of these studies have been carried out only in Western institutions.

In this research, the updated D\&M model was modified by including instructor quality and perceived usefulness as new factors relevant in e-learning contexts. The new proposed model consists of six factors: system quality, course quality, service quality, instructor quality, perceived usefulness, and learner satisfaction. Except for perceived usefulness and instructor quality, all other factors have been adapted from the updated D\&M research model. The proposed research model is shown in Figure 2, followed by the description of each factor and hypothesis.

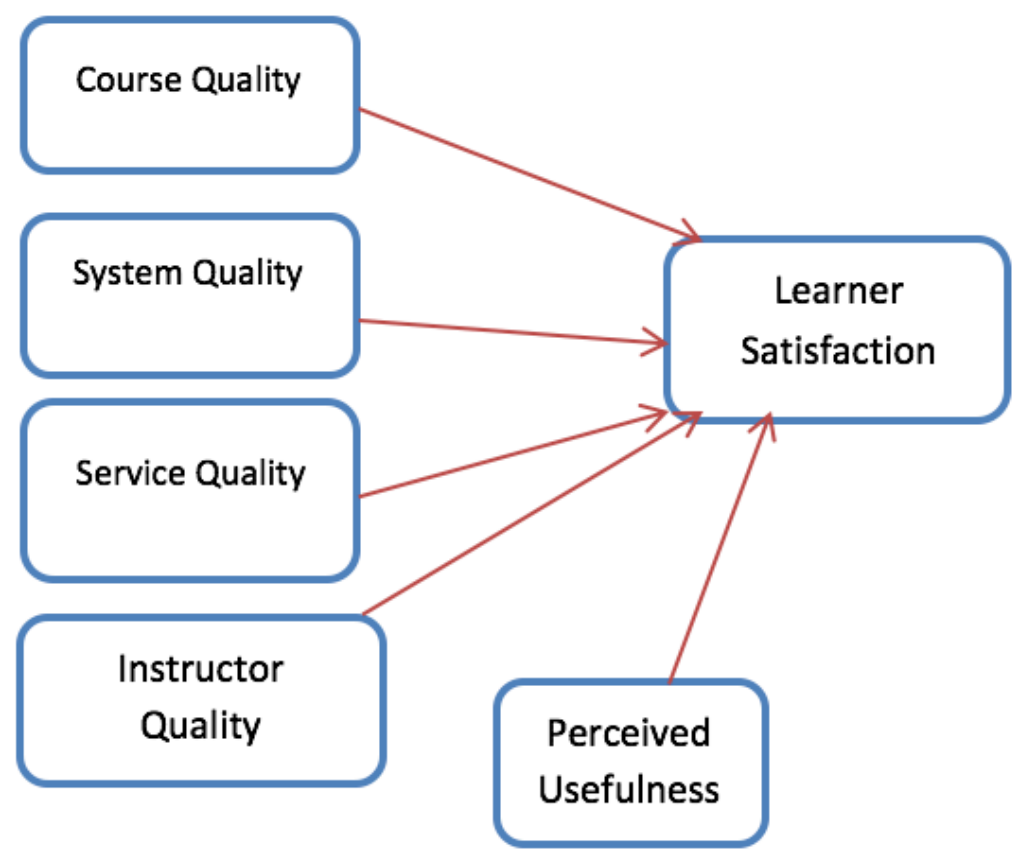

Figure 2. The proposed research model

\section{System quality}

System quality is concerned with whether the system has bugs and is easy to use (Seddon \& Kiew, 1995). The quality of the system has an impact on learners' satisfaction, especially those features that have an impact on how learners use the system. These features include ease of use, ease of learning, and user-friendliness (Petter, DeLone, \& McLean, 2008). Therefore, if the system is easy to use, learners are likely to use it more frequently, and that increased use will have a positive impact on their satisfaction. The hypothesis of this factor is:

H1: System quality has an effect on learners' satisfaction with an e-learning system. 


\section{Course quality}

Course quality is the judgement by students of the degree to which the e-learning system has valuable content that meets their needs (Adeyinka \& Mutula, 2010). Course content quality includes both content richness and update regularity (Cheng, 2012). It is measured with regard to the timeliness, accuracy, relevance, and format of the information (Seddon \& Kiew, 1995). Tarigan (2011) further noted that learner satisfaction is influenced more by the course quality than by the type of technology used to deliver the instructions. The hypothesis of this factor is:

H2: Course quality has an effect on learners' satisfaction with an e-learning system.

\section{Service quality}

According to DeLone and McLean (2003), service quality measures the quality of support services that users receive from the IT department or IT support personnel. In the e-learning context, service quality can be considered as the support services delivered by instructors and IT technicians (Ozkan \& Koseler, 2009). These services include, but are not limited to, training, hotline, and helpdesk (Urbach \& Müller, 2012). Raphael (2016) points out that the provision of student support services is probably one of the most important responsibilities of an institution and, certainly, one that can have the greatest impact on student success or failure. Therefore, it is important to include service quality as one of the factors that can have an impact on learners' satisfaction with the e-learning system at UDSM. The proposed hypothesis is:

H3: Service quality has an effect on learners' satisfaction with an e-learning system.

\section{Instructor quality}

Instructor quality is another crucial factor in understanding learners' satisfaction with e-learning systems (Cheng, 2012). It is anticipated that instructors should have both technical skills and pedagogical skills to facilitate courses offered via e-learning systems. Research has indicated that the quality of instructors significantly influences learners' satisfaction with e-learning systems (Ozkan \& Koseler, 2009; Sun et al., 2008). Cheng (2012) proposed instructor's response timeliness, teaching style, and help towards learners through the e-learning system as measurements of instructor quality. That is to say, learners' satisfaction with the e-learning system is positively affected when instructors respond to learners in a timely fashion, their teaching methods are effective, and they have control over the technology (Ozkan \& Koseler, 2009). The proposed hypothesis is:

H4: Instructor quality has an effect on learners' satisfaction with an e-learning system.

\section{Perceived usefulness}

Several studies have found that perceived usefulness has an effect on user satisfaction with various information systems, including e-learning systems (Lwoga, 2014; Seddon, 1997; Wu et al., 2006). Perceived usefulness is a "perceptual indicator of the degree to which the stakeholder believes that using a particular system enhances his or her job performance, or his or her group's or organization performance” (Seddon, 1997, p. 246). The proposed hypothesis is:

H5: Perceived usefulness has an effect on learners' satisfaction with an e-learning system.

\section{Methodology}

The target population was students who were using Moodle at UDSM. UDSM is the oldest and biggest university in Tanzania, with a population of approximately 20,000 students. The study used an instrument with 
a 5-point Likert scale ranging from 1 (strongly disagree) to 5 (strongly agree) adapted from the D\&M research model (DeLone \& McLean, 2003). However, the items were reworded to suit the context of this study. Table 1 shows the items used in the data collection for each factor and the items in the instrument.

Table 1

The items for each factor

\begin{tabular}{|c|c|c|}
\hline Factor & Code & Item \\
\hline \multirow{4}{*}{ System quality } & SQ1 & The system is easy to use. \\
\hline & SQ2 & The system is user-friendly. \\
\hline & SQ3 & The system is easy to learn. \\
\hline & SQ4 & The operation of the system is stable. \\
\hline \multirow[t]{4}{*}{ Instructor quality } & IQ1 & The instructor responds to learners via the e-learning system promptly. \\
\hline & IQ2 & $\begin{array}{l}\text { The instructor updates lecture notes on the e-learning system } \\
\text { frequently. }\end{array}$ \\
\hline & IQ3 & $\begin{array}{l}\text { The instructor responds to learners' questions via the e-learning system } \\
\text { promptly. }\end{array}$ \\
\hline & IQ4 & $\begin{array}{l}\text { The instructor responds to learners' concerns via the e-learning system } \\
\text { in a friendly manner. }\end{array}$ \\
\hline \multirow[t]{4}{*}{ Course quality } & CQ1 & The course content in the system is up-to-date. \\
\hline & CQ2 & $\begin{array}{l}\text { The courses in the system have sufficient content required for me to } \\
\text { complete the learning process. }\end{array}$ \\
\hline & CQ3 & The course content in the system is easy to understand. \\
\hline & CQ4 & Course content is in a variety of forms - audio, video, texts, etc. \\
\hline \multirow[t]{6}{*}{ Service quality } & SeQ1 & $\begin{array}{l}\text { The staff at CVL* provide prompt support through various } \\
\text { communication means, such as email, telephone, chat. }\end{array}$ \\
\hline & SeQ2 & $\begin{array}{l}\text { The training provided by CVL has enhanced my ability to use the } \\
\text { Moodle system. }\end{array}$ \\
\hline & SeQ3 & CVL staff are competent with the Moodle system. \\
\hline & SeQ4 & $\begin{array}{l}\text { CVL staff have adequate knowledge to help me if I experience any } \\
\text { problems with the Moodle system. }\end{array}$ \\
\hline & SeQ5 & The system is available most of the time. \\
\hline & SQ6 & $\begin{array}{l}\text { The system includes the contact information of technical personnel to } \\
\text { help me in case I get stuck. }\end{array}$ \\
\hline \multirow[t]{4}{*}{ Perceived usefulness } & PU1 & I find the e-learning system useful in my studies. \\
\hline & PU2 & $\begin{array}{l}\text { Using the e-learning system enables me to accomplish the learning } \\
\text { activities more quickly. }\end{array}$ \\
\hline & PU3 & $\begin{array}{l}\text { Using the e-learning system increases my knowledge in learning } \\
\text { various courses. }\end{array}$ \\
\hline & PU4 & $\begin{array}{l}\text { Using the e-learning system increases my skills in learning various } \\
\text { courses. }\end{array}$ \\
\hline \multirow[t]{3}{*}{ Learner satisfaction } & LS1 & I am pleased with the system. \\
\hline & LS2 & I am very satisfied with the system. \\
\hline & LS3 & Overall, my interaction with the system is very satisfying. \\
\hline
\end{tabular}

Note. CVL $=$ Centre for Virtual Learning.

Scale labels: 1 - strongly disagree, 2 - disagree, 3 - neither agree nor disagree, 4 - agree, 5 - strongly agree.

The questionnaire was first piloted with a group of 29 students who were enrolled in a selected course (e.g., "Database management system") to test for reliability, and minor modifications were made to suit the context of the study. The modified questionnaire was created using Google Docs and emailed to 200 students. Students' email addresses were obtained from the Moodle log file through contacting the systems administrator at the Centre for Virtual Learning, UDSM. 
A total of 153 usable responses were obtained. According to Bryant and Yarnold (1995), every analysis should be based on a minimum of 100 observations regardless of the subjects-to-variables ratio (p. 100). Therefore, the study had adequate sample size. The response rate was $76.5 \%$. The data collection was undertaken between November 2016 and January 2017. Data were analysed using Statistical Packages for Social Science (SPSS) version 20.

Out of 153 responses, $66.8 \%$ of respondents were males, and 33.2\% were females. The majority of respondents (40.5\%) had accessed two courses, followed by $23.5 \%$ who indicated that they did not access any course. Moreover, $19.6 \%$ of students had accessed one course, and $16.3 \%$ had accessed three courses.

\section{Findings}

\section{Reliability and validity}

Reliability is used to ensure the consistency of the results for the various items being tested within each component (Foster, 2001). Cronbach's alpha was used to measure the reliability of the instruments, and it was found to be 0.944 for 25 items. The value of Cronbach's alpha should be positive and even greater than 0.7 (Nunnally, 1978). The value of Cronbach's alpha for each factor is shown in Table 2; all factors meet the acceptable level.

Table 2

Cronbach's alpha coefficients for construct reliability measurement

\begin{tabular}{lll}
\hline & Construct & Cronbach's alpha \\
\hline 1. & System quality & .882 \\
2. & Course quality & .824 \\
3. & Service quality & .903 \\
4. & Instructor quality & .882 \\
5. & Perceived usefulness & .900 \\
6. & Learner satisfaction & .903 \\
\hline
\end{tabular}

\section{Sampling adequacy}

The Kaiser-Meyer-Olkin measure of sampling (KMO) was used to measure the sampling adequacy of the data. According to Kaiser (1973), a KMO below .50 is unacceptable, and factor analysis should not be performed. In this study, the KMO was .891 and confirmed the sampling adequacy. Moreover, Bartlett's test of sphericity, $p$ $<.001$, indicated that the correlation between items was sufficiently large for performing the principal component analysis.

\section{Identifying the factor structure}

Factor analysis was performed using the principal component analysis extraction method on 25 items using direct oblimin rotation with Kaiser normalisation. The aim of the factor analysis was to show whether the related items were clustered under the same construct or not. The minimum factor loadings should be .300 (Hair, Black, Babin, \& Anderson, 2009). The loadings per each item are shown in Table 3. All items in the research instrument loaded successfully. However, perceived usefulness loaded in the learner satisfaction factor. Therefore, the two factors were combined to form one factor. 
Table 3

Factor loadings on the items with oblimin rotation

\begin{tabular}{|c|c|c|c|c|c|}
\hline & SQ & IQ & $\mathbf{C Q}$ & SeQ & PU-LS \\
\hline SQ1 & .924 & & & & \\
\hline SQ2 & .880 & & & & \\
\hline SQ3 & .876 & & & & \\
\hline SQ4 & .677 & & & & \\
\hline IQ1 & & .781 & & & \\
\hline IQ2 & & .802 & & & \\
\hline IQ3 & & .773 & & & \\
\hline IQ4 & & .737 & & & \\
\hline CQ1 & & & -.521 & & \\
\hline CQ2 & & & -.649 & & \\
\hline CQ3 & & & -.617 & & \\
\hline CQ4 & & & -.633 & & \\
\hline SeQ1 & & & & .599 & \\
\hline SeQ2 & & & & .694 & \\
\hline SeQ3 & & & & .624 & \\
\hline SeQ4 & & & & .897 & \\
\hline SeQ5 & & & & .856 & \\
\hline SeQ6 & & & & .763 & \\
\hline PU-LS1 & & & & & .804 \\
\hline PU-LS2 & & & & & .663 \\
\hline PU-LS3 & & & & & .757 \\
\hline PU-LS4 & & & & & .841 \\
\hline LS-PU1 & & & & & .828 \\
\hline LS-PU2 & & & & & .797 \\
\hline LS-PU3 & & & & & .776 \\
\hline
\end{tabular}

\section{Research model summary}

Four factors were subjected to linear regression analysis to measure the success of the model and predict the causal relationship between the factors and learners' satisfaction with the e-learning system. The four factors were system quality, service quality, instructor quality, and course quality. Using an enter method, a significant model emerged: $F(4,148)=20.855, p<.0005$. The model explains $34.3 \%$ of the variance (adjusted $R^{2}=.343$ ) in learners' satisfaction with the e-learning system. Table 4 shows a summary of the research model.

Table 4

Summary showing the success of the research model

\begin{tabular}{lllll}
\hline Model & $\boldsymbol{R}$ & $\boldsymbol{R}^{2}$ & Adjusted $\boldsymbol{R}^{\mathbf{2}}$ & $\boldsymbol{S E}$ \\
\hline & .600 & .360 & .343 & .810 \\
\hline
\end{tabular}

Note. $S E=$ standard error of the estimate.

Through regression analysis, the unstandardised and standardised coefficients for each factor that explains the effect of each factor on learners' satisfaction was obtained regarding beta values. Table 5 shows a summary of the predictive factors regarding beta values for each hypothesis obtained from the regression analysis. 
Table 5

Unstandardised and standardised regression coefficients for the factors

\begin{tabular}{lllll}
\hline Construct & B & SE & B & p \\
\hline SQ & .220 & .073 & .220 & .003 \\
IQ & .164 & .076 & .164 & .032 \\
SeQ & .378 & .071 & .378 & .000 \\
CQ & -.069 & .073 & -.069 & .347 \\
\hline
\end{tabular}

The conclusion of each hypothesis is summarised in Table 6. Three hypotheses - H1, H3, and H4 - were found to be significant at values of $p<.05$ or $p<.001$, while $\mathrm{H} 2$ was not significant.

Table 6

Summary of results hypothesis testing

\begin{tabular}{|c|c|c|c|}
\hline & & Results & Conclusion \\
\hline Hypothesis 1 & $\begin{array}{l}\text { System quality has an effect on learners' } \\
\text { satisfaction with an e-learning system. }\end{array}$ & $\beta=.220, p<.003$ & Supported \\
\hline Hypothesis 2 & $\begin{array}{l}\text { Course quality has an effect on learners' } \\
\text { satisfaction with an e-learning system. }\end{array}$ & $\beta=-.069, p<.347$ & Not supported \\
\hline Hypothesis 3 & $\begin{array}{l}\text { Service quality has an effect on learners' } \\
\text { satisfaction with an e-learning system. }\end{array}$ & $\beta=.378, p<.000$ & Supported \\
\hline Hypothesis 4 & $\begin{array}{l}\text { Instructor quality has an effect on } \\
\text { learners' satisfaction with an e-learning } \\
\text { system. }\end{array}$ & $\beta=.164, p<.032$ & Supported \\
\hline
\end{tabular}

Note. Statistically significant values at $p<.05$ or $p<.001$.

\section{Discussion}

This study aimed to determine key factors influencing learners' satisfaction with an e-learning system through adopting and modifying the updated D\&M research model. Although the university has been using Moodle to support teaching and learning for 10 years now, its continued usage is determined by learners' satisfaction with the system (Bhattacherjee, 2001). Accordingly, it was important to assess learners' satisfaction with the system to find strategies that will increase system usage and eventually increase levels of their satisfaction.

The main finding from this study is that service quality was found to be the strongest predictor of learners' satisfaction with the e-learning system, contributing $37.8 \%$ of variances. The finding suggests that provision of support services to learners can potentially increase learners' satisfaction with e-learning systems. This concurs with findings of the studies conducted elsewhere (Ssekakubo et al., 2011; Sun et al., 2008; Tella, 2012). For instance, a study conducted in five institutions in sub-Saharan Africa found that poor user support hindered learners from using the e-learning system more effectively (Ssekakubo et al., 2011). Similarly, Unwin et al. (2010) found that lack of training and technical support hindered users from making full utilisation of system features in a sample of 358 respondents from 25 African countries.

The study also found that system quality has a positive effect on learners' satisfaction with e-learning systems, contributing $22 \%$ of variances. This result is in accord with studies such as those in Islam and Azad (2015), Lwoga (2014), Petter et al. (2008), Tella (2012), and Zanjani, Edwards, Nykvist, and Geva (2017). For instance, system features such as a user-friendly structure, avoidance of too many tools and links, support for privacy and anonymous posting were identified as key factors in continuing to use Blackboard at a major Australian university (Zanjani et al., 2017).

Moreover, instructor quality was found to have a positive effect on learners' satisfaction with e-learning systems, contributing $16.4 \%$ of variances. The finding is consistent with similar studies such as those in Cheng (2012), Lwoga (2014), Ozkan and Koseler (2009), and Sun et al. (2008). The finding suggests that instructors play a significant role in the use of e-learning systems. They are content experts and facilitators of course 
delivery, and manage students’ learning (Beaudoin, 1990; Ozkan, Koseler, \& Baykal, 2009; Selim, 2007). Therefore, the non-use of these systems by instructors will affect learners' satisfaction with the system. For instance, lack of time for instructors to facilitate blended courses offered via the e-learning system at University of Cape Town in South Africa hindered learners from using the e-learning system (Mlitwa, 2007). Finally, the study also found that content quality did not have a significant effect on learners' satisfaction with the e-learning system at UDSM. This hypothesis was not supported as the value of $p$ was found to be greater than 0.05 .

\section{Suggestions for future research}

In this study, the proposed research model factors were found to be statistically significantly in predicting learners' satisfaction with the e-learning system by $34.3 \%$ ( $R$ square 0.343 ) of variance. This means $65.7 \%$ of the variance cannot be explained by the factors proposed in this model. Future research could explore more factors that can be included in the research model to be able to explain learners' satisfaction with the e-learning system. Some of the factors that can be considered in the future studies include learner interface, learning community, personalisation (Wang, 2003), and access (Hisham et al., 2004).

Moreover, the present study used quantitative research method to elicit perceptions of learners' satisfaction with the system. There are still many unanswered questions as to why some factors were significant while other factors were not significant. Therefore, future research could use qualitative research methods or some form of mixed research to gain more insight on factors that significantly impact learners' satisfaction with the system. Finally, this study was limited by its relatively narrow geographical and institutional focus as it was conducted in one institution, that is, UDSM only. Similar research could be replicated in many more institutions in Tanzania or elsewhere in sub-Saharan Africa.

\section{Recommendations}

Given the proliferation of mobile phones in sub-Saharan Africa and the emergence of fibre optical marine cable, the adoption and use of various e-learning systems to enhance teaching and learning will continue to increase. The need to find strategies that will increase e-learning system success becomes critical. Existing research tends to focus on infrastructural challenges such as shortage of computers and poor Internet connectivity. Little research has investigated user perceptions of the use of these systems. This study modified the updated D\&M research model (DeLone \& McLean, 2003) to examine key factors that contribute to learners' satisfaction with the e-learning system. Service quality was found to be the strongest predictor of learners' satisfaction with the e-learning system, contributing $37.8 \%$ of variances, followed by system quality, which contributed to about $22 \%$ of variances. Based these findings, the following are recommended:

- Instructors should be trained in pedagogical skills so that they can provide reliable, timely, and effective support services to learners who use e-learning systems. Institutions should find mechanisms to incorporate pedagogical training as part of continuing professional development programs.

- Institutions should establish an IT service desk with qualified staff dedicated to provide infrastructure and technical support to learners. The technical support that needs to be provided includes networking and support in case of failure in accessing the system (Tarigan, 2011). Such support will help learners to concentrate on learning rather than on solving technical issues.

- Institutions should conduct usability testing to uncover problems that might hinder users from using the system. Many customised open source e-learning systems were not designed in consideration of the nature of users in the sub-Saharan region. In fact, many users in the region have not used several technologies before, and some started using computers when they enrolled at the university (Ssekakubo et al., 2011). Therefore, making e-learning systems easy to use and user-friendly is important. 


\section{Conclusion}

To examine the significant factors for learner satisfaction with the e-learning system at UDSM, this study used the updated D\&M model (DeLone \& McLean, 2003). The model was modified by adding instructor quality and perceived usefulness to suit the intended context. The proposed model consists of six factors: system quality, course quality service quality, instructor quality, perceived usefulness, and learner satisfaction. All six factors were subjected to linear regression analysis, which found that model variables statistically significantly predicted learners' satisfaction by $34.3 \%\left(R^{2}=0.343\right)$ of variance. The findings also revealed that all other factors except course quality had a significant effect on learners' satisfaction with the e-learning system at UDSM. However, among the factors, it was revealed that service quality is the strongest predictor of learners' satisfaction, contributing $37.8 \%$ of variances, followed by system quality, which contributed to about $22 \%$ of variances. Understanding this landscape is very useful for universities in sub-Saharan Africa and Tanzania in particular to promote the use of e-learning systems and services for teaching and learning processes. This study will help institutions in planning strategically to improve the factors that seem to have a significant effect on learners' satisfaction with e-learning systems to ensure sustainability and continued use.

\section{References}

Adeyinka, T., \& Mutula, S. (2010). Computers in human behavior: A proposed model for evaluating the success of WebCT course content management system. Computers in Human Behavior, 26(6), 17951805. https://doi.org/10.1016/j.chb.2010.07.007

Adkins, S. S. (2016). The 2016-2021 worldwide self-paced elearning market: the global elearning market is in steep decline. Monroe, WA: Ambient Insight. Retrieved from http://www.ambientinsight.com/Resources/Documents/AmbientInsight_2015-2020_US_Self-pacedeLearning_Market_Abstract.pdf

Andersson, A., \& Grönlund, Å. (2009). A conceptual framework for eLearning in developing countries: A critical review of research challenges. The Electronic Journal on Information Systems in Developing Countries, 38(8), 1-16. Retrieved from http://www.is.cityu.edu.hk/staff/isrobert/ejisdc/38-8.pdf

Au, N., Ngai, E. W., \& Cheng, T. C. E. (2002). A critical review of end-user information system satisfaction research and a new research framework. Omega, 30(6), 451-478. https://doi.org/10.1016/S03050483(02)00054-3

Bagarukayo, E., \& Kalema, B. (2015). Evaluation of elearning usage in South African universities: A critical review. International Journal of Education and Development Using Information and Communication Technology, 11(2), 168-183. Retrieved from http://ijedict.dec.uwi.edu/viewarticle.php?id=2024

Bailey, J., \& Pearson, S. (1983). Development of a tool for measuring and analyzing computer user satisfaction. Management Science, 29(5), 530-545. https://doi.org/10.1287/mnsc.29.5.530

Baroudi, J., Olson, M., \& Ives, B. (1986). An empirical study of the impact of user involvement on system usage and information satisfaction. Communications of the ACM, 29(3), 232-238. https://doi.org/10.1145/5666.5669

Beaudoin, M. (1990). The instructor's changing role in distance education. American Journal of Distance Education, 4(2), 21-29. https://doi.org/10.1080/08923649009526701

Bhattacherjee, A. (2001). Understanding information systems continuance: An expectation-confirmation model. MIS Quarterly, 25(3), 351-370. https://doi.org/ 10.2307/3250921

Booker, Q. E., \& Rebman, C. M. (2005). E-student retention: Factors affecting customer loyalty for online program success. Issues in Information Systems, 6(1), 183-189. Retrieved from http://iacis.org/iis/2005/Booker_Rebman.pdf

Bryant, F. B., \& Yarnold, P. R. (1995). Principal-components analysis and exploratory and confirmatory factor analysis. In L. G. Grimm \& P. R. Yarnold (Eds.), Reading and understanding multivariate statistics (pp. 99-136). Washington, DC: American Psychological Association.

Cai, S., Jun, M., \& Pham, L. (2007). End-user computing satisfaction and its key dimensions: An exploratory study. Southwest Decision Sciences Institute 2007, (1983), 725-734. Retrieved from http://www.swdsi.org/swdsi07/2007_proceedings/papers/725.pdf 
Cheng, Y. (2012). Effects of quality antecedents on e-learning acceptance. Internet Research, 22(3), 361-390. https://doi.org/10.1108/10662241211235699

Chitanana, L., Makaza, D., \& Madzima, K. (2008). The current state of e-learning at universities in Zimbabwe: Opportunities and challenges. International Journal of Education and Development Using ICT, 4(2), 5-15. Retrieved from http://ijedict.dec.uwi.edu/viewarticle.php?id=450

Danesh, S. Y. S., Hashemnia, S., Sirousbakht, S., \& Kia, E. (2013). Investigation of related factors to satisfying electronic learners in virtual training of Iranian universities. International Research Journal of Applied and Basic Sciences, 4(2), 477-481. Retrieved from http://www.irjabs.com/files_site/paperlist/r_701_130304203131.pdf

DeLone, W. H., \& McLean, E. R. (1992). Information systems success: The quest for a dependent variable. Information Systems Research, 3(1), 60-95. https://doi.org/10.1287/isre.3.1.60

DeLone, W. H., \& McLean, E. R. (2003). The DeLone and McLean model of information systems success: A ten-year update. Management Information Systems, 19(4), 9-30. https://doi.org/10.1080/07421222.2003.11045748

DeLone, W. H., \& McLean, E. R. (2016). Information systems success measurement. Foundations and Trends in Information Systems, 2(1), 1-116. https://doi.org/10.1561/2900000005

Docebo. (2016). Elearning market trends and forecast 2017-2021. Retrieved from https://eclass.teicrete.gr/modules/document/file.php/TP271/Additional material/docebo-elearning-trendsreport-2017.pdf

Doll, W., \& Torkzadeh, G. (1988). The measurement of end-user computing satisfaction. MIS Quarterly, 12(2), 259-274. https://doi.org/10.2307/248851

Dube, S., \& Scott, E. (2014). An empirical study on the use of the Sakai Learning Management System. In Proceedings of the e-Skills for Knowledge Production and Innovation Conference (pp. 101-107). Santa Rosa, CA: Informing Science Institute. Retrieved from http://proceedings.e-skillsconference.org/2014/eskills101-107Dube851.pdf

Elmahadi, I., \& Osman, I. (2013). A study of the Sudanese students' use of collaborative tools within Moodle Learning Management System. In P. Cunningham \& M. Cunningham (Eds.), IST-Africa 2013 Conference Proceedings (pp. 1-8). New York, NY: IEEE. Retrieved from http://ieeexplore.ieee.org/document/6701762/

Eom, S. B. (2014). Understanding eLearners’ satisfaction with Learning Management Systems, 16(2), 3-6. Retrieved from http://www.ieeetclt.org/issues/october2014/Eom.pdf

Foster, J. J. (2001). Data analysis using SPSS for Windows Versions 8 - 10: A Beginner's Guide. London: Sage. https://doi.org/10.4135/9781849208796

Hair, J. F., Black, W. C., Babin, B. J., \& Anderson, R. E. (2009). Multivariate data analysis (7th ed.). New York, NY: Prentice Hall.

Hassanzadeh, A., Kanaani, F., \& Elahi, S. (2012). A model for measuring e-learning systems success in universities. Expert Systems with Applications, 39(12), 10959-10966. https://doi.org/10.1016/j.eswa.2012.03.028

Hisham, N., Campton, P., \& FitzGerald, D. (2004). A tale of two cities: A study on the satisfaction of asynchronous e-learning systems in two Australian universities. In R. Atkinson, C. McBeath, D. JonasDwyer, \& R. Phillips (Eds), Beyond the comfort zone: Proceedings of the 21st ASCILITE Conference (pp. 395-402). Retrieved from https://www.ascilite.org/conferences/perth04/procs/pdf/hisham.pdf

Holsapple, C. W., \& Lee-Post, A. (2006). Defining, assessing, and promoting e-learning success: An information systems perspective. Decision Sciences Journal of Innovative Education, 4(1), 67-85. https://doi.org/10.1111/j.1540-4609.2006.00102.x

Horvat, A., Dobrota, M., Krsmanovic, M., \& Cudanov, M. (2013). Student perception of Moodle learning management system: A satisfaction and significance analysis. Interactive Learning Environments, 4820, 1-13. https://doi.org/10.1080/10494820.2013.788033

Islam, N., \& Azad, N. (2015). Satisfaction and continuance with a learning management system. The International Journal of Information and Learning Technology, 32(2), 109-123. https://doi.org/10.1108/IJILT-09-2014-0020

Ives, B., Olson, M. H., \& Baroudi, J. J. (1983). The measurement of user information satisfaction. Communications of the ACM, 26(10), 785-793. https://doi.org/10.1145/358413.358430 
Kaiser, H. F. (1973). An index of factorial simplicity. Psychometrika, 39(1), 31-34. Retrieved from ERIC database. (EJ105008)

Katsidis, C. C., \& Anastasiades, P. S. (2008). Assessing student satisfaction in an asynchronous e-learning environment. In J. L. Mauri, A. Zaharim, A. Kolyshkin, M. Hatziprokopiou, A. Lazakidou, M.

Kalogiannakis, K. Siassiakos, \& N. Bardis (Eds.), International Conference on Engineering Education (EE’08) (pp. 292-298). Stevens Point, WI: World Scientific and Engineering Academy and Society

(WSEAS). Retrieved from http://www.wseas.us/elibrary/conferences/2008/crete/education/education46.pdf

Lee, Y., \& Hsiao, C. (2014). An empirical examination of individual and system characteristics on enhancing e-learning acceptance. Australasian Journal of Educational Technology, 30(5), 562-579. https://doi.org/10.14742/ajet.381

Lwoga, E. (2012). Making learning and Web 2.0 technologies work for higher learning institutions in Africa. Campus-Wide Information Systems, 29(2), 90-107. https://doi.org/10.1108/10650741211212359

Lwoga, E. (2014). Critical success factors for adoption of web-based learning management systems in Tanzania. International Journal of Education and Development Using Information and Communication Technology (IJEDICT), 10(1), 4-21. Retrieved from http://ijedict.dec.uwi.edu/viewarticle.php?id=1669

Mayoka, K., \& Kyeyune, R. (2012). An analysis of eLearning Information System adoption in Ugandan Universities: Case of Makerere University Business School. Information Technology Research Journal, 2(1), 1-7. Retrieved from https://www.researchgate.net/profile/Geoffrey_Kituyi/publication/258725320_An_Analysis_of_Elearning_Information_System_Adoption_in_Ugandan_Universities_Case_of_Makerere_University_Busin ess_School/links/00b7d528df2612d143000000.pdf

Mlitwa, N. (2007). e-Learning and learning management systems (LMS) in a changing higher education environment. InVAn Belle, J.-P., \& Brown, I. (Eds.), Transforming IS \& CS Education and Research in a Changing Higher Education Environment (pp. 1-13). Retrieved from http://www.sacla.org.za/sacla2006/papers/WP07 Nhlanhla LMS in HE.pdf

Mlitwa, N., \& Van Belle, J.-P. (2011). Mediators for lecturer perspectives on learning management systems at universities in the Western Cape, South Africa. In Pacific Asia Conference on Information Systems (PACIS 2011). Brisbane: Queensland University of Technology. Retrieved from http://aisel.aisnet.org/pacis2011/135

Moodle. (2017). Registered Moodle sites. Retrieved from https://moodle.net/sites/

Mtebe, J. S. (2015). Learning management system success: Increasing learning management system usage in higher education in sub-Saharan Africa. International Journal of Education and Development Using Information and Communication Technology (IJEDICT), 11(2), 51-64. Retrieved from http://ijedict.dec.uwi.edu/viewarticle.php?id=2005

Mtebe, J. S., Dachi, H., \& Raphael, C. (2011). Integrating ICT into teaching and learning at the University of Dar es Salaam. Special Issue: Distance Education for Empowerment and Development in Africa, 32(2), 289-294. https://doi.org/10.1080/01587919.2011.584854

Mtebe, J. S., \& Raisamo, R. (2014). Investigating perceived barriers to the use of open educational resources in higher education in Tanzania. International Review of Research in Open and Distance Learning, 15(2), 43-65. . Retrieved from http://www.irrodl.org/index.php/irrodl/article/view/1803/2841

Mtebe, J. S., \& Raphael, C. (2013). Students’ experiences and challenges of blended learning at the University of Dar es Salaam, Tanzania. International Journal of Education and Development Using Information and Communication Technology (IJEDICT), 9(3), 124-136. Retrieved from http://ijedict.dec.uwi.edu/viewarticle.php?id=1690

Naveh, G., Tubin, D., \& Pliskin, N. (2010). Student LMS use and satisfaction in academic institutions: The organizational perspective. The Internet and Higher Education, 13(3), 127-133. https://doi.org/10.1016/j.iheduc.2010.02.004

Naveh, G., Tubin, D., \& Pliskin, N. (2012). Student satisfaction with learning management systems: a lens of critical success factors. Technology, Pedagogy and Education, 21(3), 337-350. https://doi.org/10.1080/1475939X.2012.720413

Nunnally, J. (1978). Psychometric theory. New York, NY: McGraw-Hill. 
Ozkan, S., \& Koseler, R. (2009). Multi-dimensional students' evaluation of e-learning systems in the higher education context: An empirical investigation. Computers \& Education, 53(4), 1285-1296. https://doi.org/10.1016/j.compedu.2009.06.011

Ozkan, S., Koseler, R., \& Baykal, N. (2009). Evaluating learning management systems: Adoption of hexagonal e-learning assessment model in higher education. Transforming Government: People, Process and Policy, 3(2), 111-130. https://doi.org/10.1108/17506160910960522

Petter, S., DeLone, W., \& McLean, E. (2008). Measuring information systems success: Models, dimensions, measures, and interrelationships. European Journal of Information Systems, 17(3), 236-263. https://doi.org/10.1057/ejis.2008.15

Raphael, C. (2016). Student support services: A case of blended learning in higher learning institutions in Tanzania. In J. Keengwe, J. Mbae, \& G. Onchwari (Eds.), Handbook of research on global issues in nextgeneration teacher education (pp. 188-205). Hershey PA: IGI Global. https://doi.org/10.4018/978-14666-9948-9.ch011

Seddon, P. B. (1997). A respecification and extension of the DeLone and McLean model of IS success. Information Systems Research, 8(3), 240-253. https://doi.org/10.1287/isre.8.3.240

Seddon, P. B., \& Kiew, M. (1995). A partial test and development of DeLone and McLean's model of IS success. Australasian Journal of Information Systems, 4(1), 90-109. https://doi.org/10.3127/ajis.v4i1.379

Selim, H. M. (2007). Critical success factors for e-learning acceptance: Confirmatory factor models. Computers \& Education, 49(2), 396-413. https://doi.org/10.1016/j.compedu.2005.09.004

Shee, D. Y., \& Wang, Y.-S. (2008). Multi-criteria evaluation of the web-based e-learning system: A methodology based on learner satisfaction and its applications. Computers \& Education, 50(3), 894-905. https://doi.org/10.1016/j.compedu.2006.09.005

Ssekakubo, G., Suleman, H., \& Marsden, G. (2011). Issues of adoption: Have e-learning management systems fulfilled their potential in developing countries? In Proceedings of the South African Institute of Computer Scientists and Information Technologists Conference on Knowledge, Innovation and Leadership in a Diverse, Multidisciplinary Environment (pp. 231-238). New York, NY: ACM. https://doi.org/10.1145/2072221.2072248

Sun, P.-C., Tsai, R. J., Finger, G., Chen, Y.-Y., \& Yeh, D. (2008). What drives a successful e-Learning? An empirical investigation of the critical factors influencing learner satisfaction. Computers \& Education, 50(4), 1183-1202. https://doi.org/10.1016/j.compedu.2006.11.007

Tarigan, J. (2011). Factors influencing users satisfaction on eLearning systems. Jurnal Manajemen Dan Kewirausahaan, 13(2), 177-188. Retrieved from http://repository.petra.ac.id/15859/1/Publikasi1_04025_374.pdf

Tella, A. (2012). System-related factors that predict students' satisfaction with the Blackboard learning system at the University of Botswana. African Journal of Library, Archives and Information Science, 22(1), 41. Retrieved from https://www.ajol.info/index.php/ajlais/article/view/106584

Twaakyondo, H. M., \& Munaku, M. (2012). A steady progress towards e-learning in Tanzania: The case of CVL-UDSM. In IST-Africa 2012 Conference (pp. 1-7). New York, NY: IEEE. Retrieved from http://www.ist-africa.org/home/outbox/ISTAfrica_Paper_ref_69_4798.pdf

Unwin, T., Kleessen, B., Hollow, D., Williams, J., Oloo, L. M., Alwala, J., ... Muianga, X. (2010). Digital learning management systems in Africa: Myths and realities. Open Learning: The Journal of Open and Distance Learning, 25(1), 5-23. Retrieved from http://www.tandfonline.com/doi/abs/10.1080/02680510903482033

Urbach, N., \& Müller, B. (2012). The updated DeLone and McLean Model of information systems success. In Y. K. Dwivedi, M. R. Wade, \& S. L. Schneberger (Eds.), Information systems theory (Vol. 28, pp. 1-18). New York, NY: Springer. https://doi.org/10.1007/978-1-4419-6108-2

Venter, P., van Rensburg, M. J., \& Davis, A. (2012). Drivers of learning management system use in a South African open and distance learning institution. Australasian Journal of Educational Technology, 28(2), 183-198. https://doi.org/10.14742/ajet.868

Vosloo, S. (2012). Mobile learning and policies: Key issues to consider mobile learning. Paris: UNESCO. Retrieved from http://unesdoc.unesco.org/images/0021/002176/217638E.pdf

Vovides, Y., Sanchez-Alonso, S., Mitropoulou, V., \& Nickmans, G. (2007). The use of e-learning course management systems to support learning strategies and to improve self-regulated learning. Educational Research Review, 2(1), 64-74. https://doi.org/10.1016/j.edurev.2007.02.004 
Wainaina, B., Sanou, B., \& Boateng, P. (2014). The eLearning Africa Report. Berlin: ICWE. Retrieved from http://www.elearning-africa.com/report2014

Wang, Y.-S. (2003). Assessment of learner satisfaction with asynchronous electronic learning systems. Information \& Management, 41(1), 75-86. https://doi.org/10.1016/S0378-7206(03)00028-4

World Bank. (2012). The transformational use of information and communication technologies in Africa. Washington, DC: Author. Retrieved from http://siteresources.worldbank.org/EXTINFORMATIONANDCOMMUNICATIONANDTECHNOLOGI ES/Resources/282822-1346223280837/Summary.pdf

Wu, J., Tsai, R. J., Chen, C. C., \& Wu, Y. (2006). An integrative model to predict the continuance use of electronic learning systems: Hints for teaching authors. The Electric Journal of E-Learning, 5(2), 287302. Retrieved from https://www.learntechlib.org/p/5781/

Xiao, L., \& Dasgupta, S. (2002). Measurement of user satisfaction with web-based information systems. In 8th Americas Conference on Information Systems (pp. 1149-1155). Retrieved from http://aisel.aisnet.org/amcis2002/159

Zanjani, N., Edwards, S. L., Nykvist, S., \& Geva, S. (2017). The important elements of LMS design that affect user engagement with e-learning tools within LMSs in the higher education sector. Australasian Journal of Educational Technology, 33(1), 19-31. https://doi.org/10.14742/ajet.2938

Corresponding author: Joel Mtebe, jmtebe@gmail.com

Australasian Journal of Educational Technology @ 2018.

Please cite as: Mtebe, J., \& Raphael, C. (2018). Key factors in learners' satisfaction with the e-learning system at the University of Dar es Salaam, Tanzania. Australasian Journal of Educational Technology, 34(4), 107-122. https://doi.org/10.14742/ajet.2993 